\title{
XLVII. On the expeditions to the North Pole
}

\section{Malte Brun}

To cite this article: M. Malte Brun (1818) XLVII. On the expeditions to the North Pole , Philosophical Magazine Series 1, 51:240, 279-286, DOI: 10.1080/14786441808637549

To link to this article: http://dx.doi.org/10.1080/14786441808637549

曲 Published online: 27 Jul 2009.

Submit your article to this journal $2 \pi$

Џ Article views: 3

Q View related articles $\asymp$ 
signing the degree of pressure equivalent to the stroke of a pile engine, the effects were not found to agree with the laws of falling hodies. M. de Cessart endeavoured to compare the percussive and pressive forces, by reducing equal cones of lead to the same thickness by the blow of a ram, and by pressure. M. Rondelet tried to accomplish the same object by means of the dymamometer of M. Regnier*; neither of these gentiemen found the effects to be proportional to the heights of the falls + ; consequently we must either suppose this law to be incorrect, or that the motion is partly destroved by the re-action of the supports. Now the experiments of Camus tend to prove the latter supposition to be correct; but the theory given in the first part of this letter does not suppose any part of the velocity to be destroyed by being transmitted to the supports, which ajpears to be the cause of the difference between it and the results of the experiments, and therefore requires to be considered anew, as it is not, in its present state, sufficiently correct for any practical purpose.

That a part of the velocity is destroyed by the supports is eacy to conceive, because, I believe it may be shown, that the velocity of the motion transmitted through the length of the bar, will be greater than that with which the point struck will descend. I am, sir, yours, \&c.

Grove End, April 14, 1818. Thomas TrEDGOLD.

XiviI. On the Expeditions to the North Pole. By M. Marte BRUN t.

Some English writers have already indulged themselves in illusory conjectures on this enterprise; they describe Greenland as bursting from the icy barrier which surrounds it. They repeat the traditionary reports of the last century, respecting some whaleships said to have reached the pole, and even to have passed on the other side of it. Thev presume to doubt the existence of land to the north of Baffin's bay, although Baffin was the best informed and most judicious seaman England could boast of; and they even flatter themselves, that conmerce will be carried on in a direct route from London to Canton, by the pole, which makes a distance of only 2,600 nautical leagues, whilst that by the Cape of Good Hope is 5,500 leagues.

Two men, however, of great authority, do not participate in these exaggerated anticipations.-Mr. Scoresby, an experienced

* Rondelet's Art de Bátir, tome iii. p. 22-32.

+ These experiments were certainly not all applicable to the case in question; that is, to establish the relation between the pressive and percussive forces, as far as regards driving piles.

$\ddagger$ From the Journal des Díbats. 
Greenland captain, thinks that the polar sens are blocked by ice, and proposes a journey to the pole by means of sledges drawn by rein-deer. Captain Burney, who accompanied the immortal Cook, has published a pamphlet, of which we have received a copy, and in which he proves clearly that there exists a large extent of land to the north of Behring's strait: he goes too far in supposing that this land probably unites the two continents of Asia and America; but it is very certain that his arguments are sufficient to contradict the opinion of the existence of an open sea.

The gratitude which the English government merits from every friend to science, ought not to prevent us from examining upon what foundation their hopes of success in this enterprise rest. It is even an advantageous justice due to the commanders of the expedition, to point out to them beforehand the immense obstacles against which they have to contend.

Fixed and floating ices may be considered as the first of these difficulties. Admitting for a moment the non-existence of a polar continent, that Greenland, New Siberia, that the land to the north of Behring's strait, and the land seen and coasted by Baffin, are in reality but four islands, (as the maps of the sixteenth century appear to represent them,) yet it is very probable, that the narrow seas which separate them are constantly choked with ice. Captain Scoresby observed the ice form itself in the open sea, at more than twenty leagues from the coast of Spitzbergen; and masses of ice arise from the bed of the sea. Thus, then, the principal argument in favour of an open sea is considerably weakened; it will be in vain for them to rely on the removal of a barrier of ice, shaken by an earthquake, or broken by the strength of the currents. The sea itself freezes, notwithstanding the assertions of $\mathrm{Mr}$. D. Barrington. This trutli once proved, eternal variations in the state of the polar seas may be expected.

From the year 1660 to 1680 , the most sanguine hopes were entertained of penetrating to the pole; yet every authenticated effort to this effect proves all exertion to have been terminated by fixed ice, which arrested the navigators' further pursuit; or by floating masses of it, which threatening to overwhelm them, compelled them to desist from their courageous enterprise. Captain Wood, who confidently believed the possibility of a passage to the north, was opposed by a continent of ice, which united Nova Zembla, Spitzbergen, and Greenland.-Captain Souter, on the contrary, continued his route to $82 \mathrm{deg} .6 \mathrm{~min}$. in a calm open channel; but the ice, on each side, begimning to connect, the dread of being blocked up obliged him to abandon his purpose. The adventurous Baffin was able once to navigate the sea which bears his name; but it has since been frequently found that this sea was filled with numerous islands, some of which were 
100 leagues in circumference, and nearly 400 feet high. Perhaps James's island, noted in several charts, was itself one of these masses of ice. Captain Wafer frankly confesses that he mistook these fixed masses of about 500 feet in height for real islands. Even the floating ice is often covered with large stones, and trees torn up by the roots, which appearance produces the idea of land. It is very uncertain whether the Dutch discovered, to the east of Spitzbergen, a tract of land, or only a mass of ice : in one of their voyages to the north of Nova Zembla, they found a bank of blueish ice, covered with soil, on which birds had built their nests. Half a centıry ago, two islands of ice were seen to fix themselves in the bay of Disco: the Dutch whale-ships visited and assigned them a name. The same eircumstance took place about Iceland.

Mr. Scoresby informs us, that the water of the sea of Spitzbergen contains only $5 \frac{3}{4}$ ounces of salt in a gallon of 231 cubical inches: its weight is to pure water as 1,0260 , and it freezes in a cold of two degrees by a thermometer centigrade. Thus it is proballe, that in the polar nights, that is to say, during our winter, the aretic seas are covered with ice. The history of different voyages furnishes us with proof of this; - but let us resume the physical discussion.

The masses of floating ice arising from the water of the sea, and which is distinguished by its porous contexture (owing to the mixture of the volatile qualities of plants), sink 4-5ths of their thickness into the salt water, the latter being in a freezing state. The masses formed of fresh water have a greater density and more transparency. Mr. Scoresby made burning-glasses from pieces of it, and lighted the pipes of the astonished sailors. These bodies sink 15-16ths of their thickness below the surface. It appears certain, that the bays and straits of the polar seas (not generally very deep) are often obstructed by these masses, resting at the bottom. The floating ices present obstacles not less redoubtable.--The concussion of the masses produces a tremendous joise, which warns the navigator with what facility his vessel would be dashed to pieces, if he were placed between two of these floating islands. It is even asserted that the wood carried off by the currents kindles by the violent collision caused by the motion of the ice; and flame and smoke arise amidst the gloom of eternal winter. Pieces of floating wood have been often found burnt at the extremities. In winter the intense cold continually occasions these mountains of ice to split asunder, and at each moment may be heard the explosion of these masses which separate in enormous chasms. In spring, the motions of the ice chiefly consist in the pupsetting of those masses, which lose their equilibrium, because some parts dissolve more rapidly than others. In all seasons the 
broken ice accumulates in the passages or gulfs, and opposes equally the attempts of individuals who expose themselves on foot, and the progress of the vessel, whose $14, \ldots$ inecomes paralysed.

If to all these considerations be added, that the ordinary course of the ices from the pole depends upon two constant and eternal canses, the seasons and the currents, the removal of the obstacles is only local and momentary; and it will be allowed that the polar seas will never afford a commercial route. Immense benefit may result to the fisheries from the discoveries which they hope to effect.

The principal argument which has been made use of, to show that the great changes in the position of the polar ice must open a passage through those dreary regions, is the pretended physical revolution, which, it is supposed, has changed the face of East Greenland. A fourishing colony, say they,-a colony embracing several towns and couvents, and containing a considerable population,- -is seen all at once shut up from the rest of the world, by a vast barrier of ice. Beside this terrible catastropthe, probably every thing suddeniy perished there; men, aninatu, vegetables, every living thing perhaps has been attacked at the satue moment with a mortal cold. If, in our time, this barrier be removed, we shall surely find this mumny of a nation, this frozen Herculaneum; nay, who knows but that some remains may be traced of the ancient Scandinavian colony? or who can say, but that, in this spot, so long inaccessible, a people may be found, who shall have preserved the language, the marners, and the catholicism of the North, as they were in the fifteenth cerstury?

This romantic prospect, however, vanishes before a critical examination of historical facts, gathered in the Sagas, works which have been much read since the discovery of Greenland. Nothing in their annals, though preserved in the bosom of their families, proves that Greenland ever enjoyed a milder climate. The establishments of the islanders there, were never more consolidated than those of the Danes on the western side, or of the British near Hudson's Bay. The voyages thither were not so freyuent or so expeditious as has been supposed: these voyages sometimes occupied five years. In 1353 , a vessel which arrived in Norway, brought there the first news of the death of the bishop of Greenlands who had died six years before. There were not many enterprising enough to undertake these voyages, and hence Greenland became the country of prodigies-the scene of the most wonderful events. For instance, Forfæus, a certain Norwegian, went over the ice from Norway to Greenland. In the latter country, he saw great forests, whose trees produced acorns 
as large as apples, and where he hunted large sea-bears! The sea there was inhabited by immense giants and giantesses: and there were to be seen mountains of ice, as lofty and as solid as those which impeded the entrance of the Argonautic experition into the Black Sea!

These are the poetic tales of the old Scandinavians, who, like Jason and Hercules, sought out danger, and defied every peril. But history is more circumspect. The Iceland book, entitled "The Mirror of Kings," gives a just idea of this country. It shows, that ancient Greenland differed in nothing from modern Greenland. The coast, even in summer, was surrounded by enormous mountains of ice, such as the Norwegians had never seen in their own country. The colonists established there, knew nothing of bread, nor were they skilled in agriculture. They exchanged the teeth and furs of some animals for wood, which they wanted for firing, and for constructing their houses. The coast was uninhabited, except in those places where there was an abundance of fish : the interior of the country, occupied by mountains arid vales covered with snow and ice, was as difficult of access as it is at this day. The number of the colonists did not exceed that of a large parish in Norway, nor would they have had a bishop, but for their great distance from the mother country. 'The Scandinavian colony in Greenland was divided into two cantons, - one west, which had but four churches, the other east, where there were two towns, or rather villages. This division gave rise to a great error in geography, from which it is supposed, that the eastern canton of Old Greenland occupied the coast opposite to Iceland; and those uuknown regions have been poinpously described as Austurbygol, in East Greenland: imaginary gulfs and promontories have been traced there; but this geographical system bas been overturned by modern accuracy.

The first navigators, on going from Iceland to Greenland, steered south-west, shumning a coast surrounded with ice; and they doubled the point of Hvarf, which is situated on the continent, but has before it an islund with a very large mountain, which they call Chemise Blanche. Following this route on the modern map, it is to be inferred, that the promontory in question is Cape Farewell, the known southern point of Greenland. The Icelanders then sailed north-west to arrive at the colony.

Other navigators have proved, that the point of Huarl is the southern extremity of Greenland, from which it must follow, that East Greenland is only a portion, in fact, the most eitetern and southern part of the west coast. The name of Greenland is justified only by the verdure of some tufts of grass and a few Howers, which show themselves in June, towards the south. 
Higher up, nothing is to be seen but ice; and ice so accumulatect and impenetrable, as to repel the boldest pirates. The current, whose continual direction is south-west, floats towards this coast, extending for ten degrees of latitude the sheets of ice which come from Spitzbergen. This has been the case for two centuries; and hence it is extremely probable, that this coast was never accessible. It is not here that the ice has latcly disappeared ; it is higher north, where the ruins of the old Norman hamlets and churehes have been discovered. These ruius bear traces of violent destruction by a hostile force. Perhaps, also, the plague, which ravaged Europe in the fourteenth century, was extended to Greenland. The commerce with this colony having become a droit of the queen of Norway, the monopoly accelerated the decline of the establishment. But a bull of pope Nicolas $\mathrm{V}$. proves that the destruction of the colony was caused by a foreign invasion; a fleet, nobody knows whence, attacked and devastated the country; all was annihilated by fire and sword. This fleet probably belonged to Prince Zichno or Sinclair, lord of the isles of the Orcades and of Finland, whose two brothers Nicolo and Antonio Zeni decried the expedition as piratical.

These explanations, which make the wonders of East Greenland disappear, have not been received without examination, and without opposition. In a memoir printed in the Danish language, and which is deposited in the Royal Library at Paris, a lientenant of marine, M. de Wormskiold, attempts to prove that old East Greenland must exist on the eastern coast between the $62 \mathrm{~d}$ and 64 th parallels of latitude. These arguments are taken from the "Voyage of Danell," a book not deemed authentic.

Denmark has left nothing untried to decide the problem. Many attempts have been made by that power, both by sea and land. In 1783, Lieutenants Egede and Bothe sailed up the eastern coast as far as 63 degrees parallel: the ice prevented them from going further. The coast presented the most dismal prospect.

Nothing discovered in modern times proves those changes in the climates, those great physical catastrophes, with which some writers, full of imagination, have endeavoured to animate the picture of the polar regions.

The idea of being winter-bound in the midst of the glacial regions, frightens the imaginations of those who have read the relations of Berendt and Heemskerk : but these two Dutch mariners had foreseen, had prepared nothing; shipwreck consigned them, without defence, to the horrors of a polar winter. The English navigators bave calculated the dangers, and provided the means for withstanding them; they do not appear to doubt the possibility of supporting the cold, even under the pole :-perhaps uature may furnish them with some facilities which they do not 
expect. The polar countries, such as Iceland and Greenland, abound in warm, and even boiling, springs. Who has not read the descriptions of the Geyser, that marvellous boiling waterspout, which surpasses in magnitude all the jets d'eau which art has produced? But the oconomical use which may be made of these singular fountains, is not so generally known. The historian Snorron, the Herodotus of the North, and a long time judge or president of the republic of Iceland, made a bath for a hundred persons to be constructed, which still exists; and the water of which is furnished from a natural source. Some monks, who settled in Greenland in the middle age, went a step further; they heated their monastery with the vapour of boiling springs. The following is the curious account of it given by the brothers Zeni.

"There is," he says, " in this place (the monastery of Saint Thomas) a spring of boiling water, with which the monks heat the church, the refectory, and their cells; when it arrives at the kitchen, the water is still so hot, that they have no need of fire to prepare their meats. To make bread, it is sufficient to put the paste into copper-vessels, and to hold these in the water; the bread becomes baked in this manner, as if it were in an oven. He found also in this monastery, small gardens in full, vegetation in winter; the monks irrigate them with this water, and by this means grow flowers, ripen fruits, and rear different. sorts of plants, which vegetate as well as if they were favoured with a temperate climate. The rude savages, who inhabit these countries, astonished at effects which they regard as supernatural, take the monks for gods; and carry them all sorts of presents, sweh as birds, meat, and various other things."

Although the situation of this monastery cannot now be traced, the relation is too circumstantial to permit of our supposing it to be an imposture, though, perhaps, there may be some confusion in respect of places. "The monks," continues the narrative, "employ no otlier materials for the building of their monastery"; than what are supplied by the neighbouring volcano; they take, for this purpose, the stones which are ejected in the form of scoria from the crater of the mountain; and while they are yot hot throw water upon them, by which means they are entirely dissolved, and converted into an excellent lime. The sçoria, when it is cold, serves in place of stones to form very solid walls and arches; for when once cooled, it cannot be broken but by an instrument of iron. The arches made with this scoria are so light, that they do not require any support. The want of rain is never felt as an inconvenience in this country; for the first snow which falls remains frozen for the space of nine months, the time which winter lasts. 'The people live upon wild birds and fish.

$$
\therefore \text { The }
$$


“ The hot water of the volcano, falling into a large haven, prevents the sea from freezing, in consequence of which, so great a quantity of birds and fish are attracted to this place, that the religious draw from them as much as is necessary for their own subsistence, and for that of a great number of the inhabitants of the country, whom they constantly employ in building, in hunting, in fishing, and various other occupations."

The narrative treats afterwards of the barter trade, which these monks carry on with Norway and Iceland.

"During winter a great number of ships are always to be found here, which cannot get away in consequence of the sea being completely frozen, and therefore wait the return of spring."

The old chart, designed upon wood, which exhibits the course of the navigation of the brothers Zeni, represents Greenland under a figure approaching that which is now given to it, and under the double name of Grolandia and Engroenland.

The monastery of $\mathrm{St}$. Thomas is placed there at three degrees northward of the island; a position which answers to that of Point Charn, where the whalers have met with foating 'pieces of hollow stone. It is also about this place that Vólkart Boon, a whaler of Sleswick, discovered in 1761 a large gulf.

The details which the Zeni give with respect to the houses and canoes of the savage inhabitants of the country, coincide exactly with all that we know of the present Esquimaux of Greenland.

"The canoes of the fishermen of Engroenland have the form of a weaver's shuttle; they are made of the bones of marine animals, covered with several plies of fish-skins sewn together. These canoes are so impermeable and so solid, that in the greatest tempests, the persons who are in them content themselves with remaining at their ease, without caring where the winds or waves maybear them, well persuaded that their canoes run no risk of being broken or submerged; should it even happen that they are thrown upon a rock, they sustain no damage."

It would be a singular event to see the English re-discover the monastery of Saint Thomas, or some similar locality. If in the fourteenth century, some poor preaching friars were able to create a commodious habitation and a smiling garden in the midst of eternal ice, what may not the enlightened industry of the nineteenth century achieve? Were a small colony of learned men to sojourn for some years in a similar place, it would enrich science with precious discoveries. Magnetism, universal gravitation, the aurora borealis, and many ather phænomena, could in no place we observed with more advantage.

[To be continued.] 